\title{
THE UNIVERSITY OF WARWICK
}

University of Warwick institutional repository: http://go.warwick.ac.uk/wrap

This paper is made available online in accordance with publisher policies. Please scroll down to view the document itself. Please refer to the repository record for this item and our policy information available from the repository home page for further information.

To see the final version of this paper please visit the publisher's website. Access to the published version may require a subscription.

Author(s): Asaf Federman

Article Title: What Kind of Free Will Did the Buddha Teach?

Year of publication: 2010

Link to published version:

http://dx.doi.org/ 10.1353/pew.0.0086

Publisher statement: None 


\section{THE UNIVERSITY OF WARWICK}

University of Warwick institutional repository: http://go.warwick.ac.uk/wrap

This paper is made available online in accordance with publisher policies. Please scroll down to view the document itself. Please refer to the repository record for this item and our policy information available from the repository home page for further information.

To see the final version of this paper please visit the publisher's website. Access to the published version may require a subscription.

Author(s): Asaf Federman

Article Title: What Kind of Free Will Did the Buddha Teach?

Year of publication: 2010

Link to published version:

http://dx.doi.org/ 10.1353/pew.0.0086

Publisher statement: None 


\section{Project \\ MUSE \\ Today's Research. Tomorrow's Inspiration.}

\section{What Kind of Free Will Did the Buddha Teach?}

\section{Asaf Federman}

Philosophy East and West, Volume 60, Number 1, January 2010, pp. 1-19 (Article)

Published by University of Hawai'i Press

DOI: 10.1353/pew.0.0086

Philosophy East and West

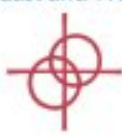

A Qusrterily of

Comparatioe Plibosopily

Woure 60 , Nunter 2

For additional information about this article

http://muse.jhu.edu/journals/pew/summary/v060/60.1.federman.html 
WHAT KIND OF FREE WILL DID THE BUDDHA TEACH?

\section{Asaf Federman}

Department of Psychology, University of Warwick

\section{Introduction}

The modern version of the problem of free will is usually described as a collision between two beliefs: the belief that we are free to choose our actions and the belief that our actions are determined by prior necessary causes. Determinism - the view that events are determined by specific causes-makes most aspects of reality intelligible. It works quite well, for example, when explaining aspects of the natural world (quantum physics aside). When heat, fuel, and oxygen come together there is fire. There must be fire. To borrow a famous Buddhist simile, when a mango seed is given the right conditions, it will grow to become a mango tree. It cannot grow to be anything else. However, we do not usually think of agents as being caused in the same way. We tend to think that agents somehow transcend natural causation by their ability to choose freely. If we also think that agents are part of the natural order, we face a paradox. This is, in short, the problem of free will.

On the face of it this problem applies to Buddhism as well. Buddhist thought is very much dedicated to explaining reality as a series of causal relations between processes. This, together with the rejection of a transcendent soul, seems to contradict the Buddhist insistence on choice, personal responsibility, and retribution. Surprisingly, the subject of free will in Buddhism has remained somewhat marginalized in Buddhist scholarship. This has left a void that has attracted contradictory claims: either that Buddhism allows no free will or that it is a doctrine of free will per se. ${ }^{1}$ This article aims at counterbalancing this situation by comparing the Buddhist position, as preserved in Pâli sources, with a recent proposal by the philosopher Daniel Dennett, who advocates a compatibilist solution to the traditional problem of free will. It argues that Dennett and the Buddha represent two similar conceptual shifts: from ultimate free will to compatible free will. ${ }^{2}$ Dennett criticizes the Cartesian notion of the soul as the ultimate inner controller of the body and replaces it with a dynamic notion of intention that is dependent on the agent's cognitive ability to reflect, plan, and control. Similarly, the Buddha rejects the Brahamanical concept of soul as the ultimate controller and replaces it with a dynamic notion of intention. The parallels between the rejections of Cartesianism and Upanișadic Brahminism show that although the Buddha rejected ultimate free will, he accepted a compatibilist free will that allows self-control and moral choice.

This article begins with a critical review of the secondary literature on free will in Buddhism. It progresses by comparing the Brahamanical notion of free will with the Cartesian notion. It discusses the arguments that are used by Dennett and the 
Buddha in order to reject ultimate free will, and presents a positive account of the kind of free will the Buddha taught, using the conceptual tools laid out by Dennett. Finally, it addresses the question of the compatibility of determinism and free will. It argues that the Buddha's position is closer to accepting determinism than to rejecting it, and that determinism is compatible with the kind of free will that the Buddha taught.

\section{Review of Secondary Literature}

As mentioned above, there is little published on free will in Buddhist scholarship. The collection Freedom and Determinism contains a chapter on Buddhism by Gier and Kjellberg that compares the Buddhist doctrines from the Pāli Canon and from Nāgārjuna with Western philosophies from the ancient Greek to Modern Europe. ${ }^{3}$ Although this chapter begins to do justice to the long-neglected subject, its broad scope eventually leads to an unsatisfying conclusion: that Buddhism is silent about free will because its conceptual tool kit is different from the modern tool kit.

An earlier article by Luis Gómez contains some preliminary insights from the Pāli. ${ }^{4}$ It presents the problem of free will as a tension between choice and determinism and concludes that Buddhism suggests a "middle way" between the two. Gómez argues that this is possible only if causality, or karma, in Buddhism is understood as "weak determinism." Unfortunately this concept is not adequately explained or developed. Although the article presents an interesting analysis of some Pāli passages, it compromises the philosophical side.

Mark Siderits provides a more detailed philosophical argument for Buddhist compatibilism; however, his article suffers from a lack of references to primary sources, a fact that led him to unnecessary complications. ${ }^{5}$ Although he argues that in Buddhism personal freedom and psychological determinism relate to each other like "two ships passing each other in the night,"6 he admits that the Buddhist rejection of ātman practically cancels the possibility of free will:

If ultimately there are no persons but only physical and mental events in a complex causal series, then the ultimate truth about "us" must be that "we" are not free. ${ }^{7}$

After that he tries to "save" freedom by suggesting that believing in freedom is necessary because "otherwise there would be no explaining the utility of the concept of freedom." 8 This is a problematic argument that tries to derive the existence of freedom from the mere existence of the concept of freedom. However, taking this path is unnecessary, because-as suggested below —although the Buddhist doctrine of not-soul rejects the idea of ultimate self-control, this does not lead to denying that people control their behavior and choose their actions.

There are other references to the question of free will and determinism in textbooks and monographs. Here are two examples that illuminate, again, the problem scholars face when dealing with free will in Buddhism. In his Buddhist Logic Stcherbatsky writes that "the Special Theory of Causation has been established by Buddha himself in defense of Free Will and against a theory of wholesale determinism." ${ }^{9} \mathrm{He}$ 
bases this observation on the famous Buddhist rejection of the fatalistic position of Makkhali Gosala, who denied absolutely all free will and all moral responsibility. ${ }^{10}$ Here, in Stcherbatsky's view, the Buddhist rejection of Makkhali's fatalism is equated with the rejection of determinism and leads to the defense of free will. Thus, in this interpretation, the Buddha accepts free will.

Walpola Rahula, on the other hand, describes the Buddhist position in the following words:

If Free Will implies a will independent of conditions, independent of cause and effect, such a thing does not exist. How can a will, or anything for that matter, arise without conditions, away from cause and effect, when the whole of existence is conditioned and relative, and is within the law of cause and effect? ${ }^{11}$

Here, in Rahula's view, the Buddhist doctrine of causality overrides the possibility of independent free will (cf. Wallace in note 1 above). Determining the Buddhist position on free will requires a clearer analysis of the terms involved in the discussion. Does free will mean something that is "independent of conditions, independent of cause and effect"? Or does it mean the opposite of fatalism? The first step in answering these questions is to acknowledge that there are in fact two different definitions of free will. The first defines free will as a power that belongs in the soul, transcends the physical, and has ultimate control over the body (FW1). The second defines free will as the agent's ability to control action in conformity with will, when there are no constraints that limit performance (FW2). The shift from one definition to the other characterizes the philosophical atmosphere today and has characterized the Buddhist position in the early days. Much of the confusion in Buddhist scholarship is caused by mixing these two kinds.

\section{The Cartesian Notion of Free Will and the Upanișadic Notion of Ultimate Control}

The problem of free will is a product of European thought and is rooted in medieval theology. As expressed by Augustine of Hippo, the will to do evil poses a tremendous difficulty to the believer who accepts the existence of an all-powerful, benevolent creator God. ${ }^{12}$ This difficulty is then generalized to encompass the entire realm of moral choice, and eventually human conscious choice in general. Thirteen hundred years after Augustine of Hippo, when Descartes articulated his "proof" of free will, he called upon a very similar notion of God to aid his argument for ultimate free will. ${ }^{13}$ Indeed this notion of free will cannot simply be imposed on Buddhism, which rejects the idea of an all-powerful Deity.

As mentioned above, the problem of free will and determinism, which lies dormant at the core of the Cartesian position, is about how to reconcile the view that the physical world is governed by mechanical causation and the view that people have free choice. In history there were various attempts to solve this problem of which two are most illuminating for understanding the Buddhist stance. The first is called here "Cartesianism" (after René Descartes), and the second is called "compatibilism" because it argues that freedom and determinism are compatible. The first to 
articulate the compatibilist position was probably Hobbes, who defined a free man as somebody who finds "no stop in doing what he has the will, desire or inclination to do." ${ }^{14}$ Agents are more free when they are less limited by constraints, coercions, lack of opportunities, and compulsions. Descartes, on the other hand, sees free will as a Godly power that belongs in the soul. In the fourth chapter of Meditations on First Philosophy he states:

I ... can not complain that God has not given me a free choice or a will which is sufficient, ample and perfect, since as a matter of fact I am conscious of will so extended as to be subject to no limits.... It is the free-will alone or the faculty of choice which I find to be so great in me that I can conceive no other idea to be more great; it is indeed that case that it is for the most part this will that causes me to know that in some manner I bear the image and similitude of God. ${ }^{15}$

Free will in this case is "ample and perfect" and is "subject to no limit." Descartes' understanding of free will stems from his ontological standpoint, which is known as "substance dualism." Will is a power that belongs to the soul, to the immaterial substance. This power can influence the material substance by causing the body to move. In The Passions of the Soul Descartes writes: "the little gland in the middle of the brain can be pushed to one side by the soul and to the other side by the animal spirits."16 The "animal spirits" can be understood as bio-mechanical forces that originate from neither will nor reason. Descartes was aware of the fact that human behavior is influenced by various forces (e.g., instincts and emotions), but he claimed that the will could override them, especially when combined with reason. These two immaterial faculties exercise a top-down causality-from soul to action.

Descartes and his followers argue that free will belongs in the soul and that the body is subject to mechanical causality. According to this view, freedom cannot arise from a determined physical process. It must come from somewhere else. Determined processes may cause desires and instincts to arise, but true free decisions are not bound to the physical. They rule it. They control it.

Let us consider a contemporary example. John Foster introduces the requirements for free will as follows:

The non-physical subject has a genuine power of choice, whose operation is not constrained by prior physical or psychological conditions, and which enables him to exercise an ultimate control over the movement of the body. ${ }^{17}$

First, the agent is required to be non-physical, because the physical world, as we know, is governed by causality. Second, the agent should have a genuine power of choice and an ability to exercise ultimate control over movement. Anything less than that, according to Foster, would not account for freedom.

Scientists are less attracted to the idea of non-physical substances. The idea that a non-physical agent somehow imposes freedom on a closed causal system contradicts essential aspects of scientific thought, namely that the brain controls the body, 
and that the brain is part of the deterministic physical world. A rigorous materialistic approach would dismiss free will as unreal or illusory. Actions and choices are primarily produced by brains. Being part of the physical world, brains do not transcend causality and therefore cannot be genuinely free. ${ }^{18}$ However, in the face of our intuition about ourselves, and the fact that we exhibit many signs of being able to choose, some hesitate to claim that free will is just an illusion, and insist that there is a genuine problem with it. ${ }^{19}$

Nevertheless, even the position of those who think that free will is nothing but an illusion falls under the category of "Cartesianism" because it is based on the assumption that without an immaterial soul that transcends causality there is no place for genuine free will. This is the first kind of free will that was mentioned above (FW1).

This kind of free will is virtually identical to one view that can be found in the Upanișads, and that is rejected by the Buddha. Some Upanișadic passages suggest a strong association between soul (ātman) ${ }^{20}$ and control. On top of the common Advaita interpretation that sees ātman only as an ultimate locus of perception, ${ }^{21}$ these passages suggest that it is also an ultimate locus of control. In the Brhadāraṇyaka Upanișad (BrU) the priest who knows the secret meaning of ritual verses is described as all-powerful: "He is able to produce by his singing whatever he desires, either for himself or for the patron of the sacrifice." 22 Passages like this lead Steven Collins to argue that Brahmanical practices and theology contain an important component of control: the priest who knows the ritual gains control over the universe. ${ }^{23}$

In the Brahmanical context knowledge is control. Knowing the ritual gives the priest control over the sacrifice, and hence over the universe. This principle is sometimes transformed in the Upanișads in the following way: one who knows the soul (ātman) gains control over the ultimate principle of the universe (Brahman), because they are, in the final account, identical. This is based on two principles: (1) a knowledge of things gives power over them, and (2) things of different scale may be identical. Thus, knowing means controlling, and controlling allows those who know to gain whatever they wish. In the same manner the renouncer gains ultimate control through the "internal ritual," through knowing the soul: ${ }^{24}$

The soul (ātman) of yours who is present within but is different from the earth, whom the earth does not know, whose body is the earth, and who controls the earth from withinhe is the inner controller (antarayāmin), the immortal. ${ }^{25}$

This passage is repeated with the word "earth" being replaced by various features like water, fire, and the sky. Ätman is repeatedly described as an inner controller (antarayāmin), and at the end it is also described as the center of perception. ${ }^{26}$ The ontology of the Upanișads is very different from that suggested by Descartes. The latter, as pointed out above, is very much embedded in Christian Theology. Nevertheless, both descriptions of inner control share the following features: (1) the inner controller is the soul, or the true essence of being, (2) it controls the body, and (3) it is different from the body. This could be mapped onto the definition of FW1: a 
power that belongs in the soul, that transcends the physical and that has ultimate control.

\section{The Buddha's Rejection of Ultimate Free Will}

In Buddhist thought freedom does not require an immortal and immaterial substance that transcends the causal order. The Buddha denied the concept of soul and at the same time taught choice, individual responsibility, and personal retribution. In the Cartesian context the soul serves as an ultimate source of control, and a very similar idea is found in the Upanișads. Nevertheless, it is denied in early Buddhism and is replaced by a dynamic volitional process, which is embedded in causality.

In the passages from the Upanișads that are quoted above, àtman is the inner controller. Knowing ātman gives the knower ultimate control and ultimate freedom to influence his destiny. By knowing ātman one becomes one's own master and gains freedom of movement. The metaphor of mastery is echoed later in Buddhist texts, and stresses that the Buddha rejected ātman not only as a center of perception, but also as the center of control (more on this later).

If knowledge of ātman is indeed so crucial for being one's own master, being free and self-controlled, what should we make of the Buddha's claim that no attman can be found? There are two options. (1) With the rejection of ātman the Buddha provided a new source for ultimate free will. Or (2) with the rejection of àtman the Buddha rejected the idea of ultimate self-control and therefore rejected the idea of an ultimate free-will. The first hypothesis can easily be ruled out. Pāli texts do not suggest any alternative substance as the origin of ultimate control. They discuss reality in terms of processes, not in terms of substances. In such a reality there is action but there cannot be an ultimate source for action. The search for ultimate control must, then, be futile. If ultimate control is the definition of free will then the Buddha must have denied it.

On the other hand, we expect that a system that stresses personal responsibility in both the moral and soteriological dimensions will also provide a theoretical account of how individuals are agents, ultimate bearers of responsibility, and ultimate initiators of action. In other words, we expect such a system to have a theory of ultimate agent causation and free will. But Buddhism fails to meet this expectation. Buddhist arguments systematically shift the attention from agent causation to a causal sequence of impersonal processes.

One sutta of the Saṃyutta Nikāya expresses the Buddha's refusal to commit to a theory of agent causation regarding the origin of suffering. There, Sāriputta is asked where the Buddha stood on a certain controversy, which is expressed in the Indian quadruple proposition: is suffering created by oneself, by another, by both, or by none? ${ }^{27}$ Although there is no reference here to one's soul (attā), there is reference to oneself (sayam). The word sayam is derived from the Vedic sva, meaning "own." The question is therefore about the "owner," or the agent, by which suffering is produced (katam). But the Buddhist answer shifts the attention away from agency alto- 
gether. It simply states that suffering is created by contact (phassa) and later explains the causal process in more detail using the language of impersonal causation. In this sutta the causal analysis is said to be true whether you think that suffering is caused by self, another, both, or none. It renders the question of agent causation as irrelevant; instead it suggests that suffering is "dependently arisen" (paticcasamuppanna).

In other places, theories about the agent's center of gravity, the soul, are also rejected and with them the idea that agents have ultimate control over other aspects of reality. ${ }^{28}$ This is clearly illustrated in one of the most important discourses of the Pāli canon, the Ānattalakkhana-sutta, where the Buddha expounds the doctrine of not-soul (ānatta) to his five former companions. The Buddha states:

Body is not soul. For if body were soul this body would not lead to affliction, and it would be possible to have it of body: "Let my body be thus; let my body not be thus." But because body is not soul it leads to affliction [; it is not possible to have it of body: "Let my body be thus; let my body not be thus." 29

This passage is repeated five times with "body" being replaced by each of the remaining four "aggregates" (khandha) that constitute the mind-body phenomenon: sensations, apperceptions, volitions, and consciousness. ${ }^{30}$ Any of these, it is said, is not soul because (a) it leads to suffering, and (b) it cannot be changed at will. These passages contain two arguments.

First argument

1. If body was soul, and soul could not lead to affliction, then body does not lead to affliction.

2. It is not true that body does not lead to affliction.

3. Therefore it is not true that body is soul.

Second argument

1. If body was soul, it could be changed at will.

2. It is not possible to change body at will.

3. Therefore body is not soul.

The first argument is based on the hidden assumption that soul could not lead to affliction. This echoes the Brahamanical assertion that knowing ātman leads to ultimate bliss. ${ }^{31}$ The second argument is based on the following assumption: soulas-aggregate means an ability to change the aggregate at will. The conclusion does not say that soul does not exist, but rather says that none of the five aggregates is soul. More interesting than the conclusion is the premise, which says that soul entails entertaining ultimate agent causation ("Let my form be thus; let my form not be thus"). The text takes it for granted that if soul-as-aggregate exists, then the aggregate could be directly manipulated. Although it does not explicitly say the soul controls the aggregates, it does associate the existence of soul-as-aggregate with the ability to control. 
The same line of argument is repeated in detail in the Cūla-saccaka-sutta, ${ }^{32}$ which contains an additional simile that stresses the connection between soul and control. The Buddha describes how a king rules his kingdom. Then he asks Saccaka to confirm that soul must have the same kind of control over the aggregates. If the aggregates were soul, says the Buddha, then one would rule them as a king rules his kingdom. The conclusion echoes the Ānattalakkhana-sutta: soul cannot be found within the aggregates because one cannot change the aggregates at will.

These arguments against àtta and for anattā assume a connection between soul and ultimate control. Taking any of the aggregates to be the essence of being, the soul, would mean that it could be manipulated at will. As shown above, this connection is not foreign to ancient Indian thought. The Buddhist denial of soul includes a denial of such ultimate control, thus taking for granted ideas that are found in some passages of the Bṛhadāraṇyaka Upanișad. Although there is no agreement among scholars on whether the Buddha had any knowledge of the Upanișads, it becomes clear that the association between soul and control was taken for granted by the Buddha when he formulated his arguments for ànatta. With the rejection of the soul, the Buddha also rejected ultimate free will.

Dennett's neo-compatibilist reaction to the Cartesian conception of free will shares some features with the Buddhist rejection of the Upanișadic idea of an ultimate controller. The most obvious resemblance is the rejection of ultimate soul as the source for free will. As mentioned above, the Buddha rejected the Brahmanic idea that humans can find a soul (ātman) that is identical to a divine power (Brahman). Dennett, too, rejects that traditional idea that free will is "a God-like power to exempt oneself from the causal fabric of the physical world." ${ }^{33} \mathrm{He}$, like the Buddha, is convinced that we do not have immaterial souls in that sense. ${ }^{34}$ The structure of the justification for this conviction is similar in both the modern and the Buddhist cases: the idea that we have souls is simply not supported by anything we have learned from experience or experimentation. ${ }^{35}$ This already is at odds with the definition of free will that is given above (FW1). However, it agrees with the compatibilist definition of free will that is endorsed by Dennett and can be extracted from Buddhist doctrine.

\section{The Buddha and Compatibilist Free Will}

The classical compatibilist solution to the problem of free will shifts the attention from ultimate agency to the more tangible freedoms people have. People are free whenever they can do what they want to do, that is, when there are no constraints on choice and execution. To this notion of compatibilist free will Dennett adds an important cognitive perspective that works well with the Buddhist psychological attitude. (He also adds an evolutionary perspective that has no Buddhist counterpart, which will not be discussed here.) He perceives free will as a kind of self-control that is based on a unique set of cognitive skills: to represent, to reflect, and to imagine possibilities. In his words: 
We are the only species whose members can imagine the adaptive landscape of possibilities beyond the physical landscape, who can "see" across the valleys to other conceivable peaks.... We can conceive (we think) better worlds and yearn to get there.... Our evolved capacity to reflect gives us - and only us - both the opportunity and the competence to evaluate the ends, not just the means. ${ }^{36}$

People imagine possibilities, and aspire to achieve what they think is best among them. This process is not linear. It is subject to constant evaluation and reevaluation according to knowledge that has been accumulated. The more accurately one represents reality and imagines possibilities, the more freedom one has. Free will is, therefore, our imperfect ability to control ourselves, to direct ourselves (our bodies, to begin with) toward the imagined goal. Free will in this sense is necessarily a property of an agent who wants something, and who can drive himself in the direction of fulfilling the desire. ${ }^{37}$ This is the second kind of free will that is mentioned above (FW2): an agent's ability to control action in conformity with his will when there are no constraints, coercions, and compulsions that limit performance.

Although FW1 is rejected by the Buddha, FW2 is consistent with Buddhist doctrine. In fact, the Buddhist path-that is, the path to freedom (vimuttimagga) ${ }^{38}$ aims exactly at the eradication of coercion, constraint, limitation, bondage, and so on. Buddhist texts focus mostly on mental constraints (a partial list would contain the three roots of suffering and the five hindrances), ${ }^{39}$ whose eradication is often compared to becoming free from slavery, bondage, debt, and sickness. ${ }^{40}$ Those who are not yet liberated are bound by various mental bondages (bandha) that limit the mind and obstruct freedom. Finally, nibbāna, the ultimate goal of the path, is referred to as freedom in the compatibilist sense. In David Kalupahana's words: "The term nibbāna (Skt. nirvāṇa) conveys the same negative sense associated with the conception of freedom whenever the latter is defined as 'absence of constraint.'" 41 The eradication of mental constraint is the core of the Buddhist path to freedom, and there is little doubt that the Buddha thought that such freedom is achievable.

Besides the absence of constraint, the compatibilist definition of free will requires also an agent that is capable of monitoring wishes in order to execute actions. Although the Buddha denied ultimate agency — the singular point from which soul ultimately controls the body-he acknowledged moral choice and personal retribution. The agent in this case is nothing but a collection of physical and mental processes, but as such it can still choose what to do. The Buddha rejected the view, attributed to Makkhali Gosala, that there is no self-agency (attakāra) ${ }^{42}$ and replied to another question on the same subject that people have an "ability of initiating" (ārabbha-dhātu). ${ }^{43}$ Some other Pāli terms that fall under the English "intention" sañcetanā, sankappa, cetanā-indicate that for the Buddha a person is able to consciously plan and direct action. Being part of the eightfold path sammā-sankappa is singled out as a function that can direct behavior toward non-harm and renunciation. ${ }^{44}$ Cetanā is singled out as equally important when the Buddha declares that it defines action with moral consequence (kamma). ${ }^{45}$ Denying intention, that is, the 
ability to plan and deliberate action, would be similar to accepting the fatalistic doctrine of Makkhali Gosala.

The last component that is required for free will is the ability to be aware of one's own desires and wishes. Mindfulness (sati) is probably the single most important cognitive function that is responsible for this task in Buddhist psychology. It is part of the eightfold path (sammā-sati) and can be developed through practice. It allows the practitioner to know the current state of the body, bodily movements, feelings, mind (citta), and mental states (dhamma). ${ }^{46}$ When one knows one's state of mind, desires, and wishes, one can consider a course of action. As long as there are no constraints, one can act accordingly.

However, constraints refer not just to physical limitations that prevent the execution of action but also to psychological limitations that may interfere with planning itself. The Buddhist treatment of freedom is notably psychological and takes into account the level of mental constraints. Unlike some libertarian positions that emphasize only the freedom of action, Buddhist liberty primarily refers to the mind being free from what binds it. This notion directly stems from the Buddhist understanding that the mind "foreruns" or precedes the rest of the phenomenal world, including action. ${ }^{47} \mathrm{~A}$ free mind is therefore a necessary condition for other kinds of freedoms like freedom of speech, choice, and action, which all come under the compatibilist definition of free will.

The importance of mental freedom at the level of planning is illustrated in postcanonical discussion of a Jataka story in the Questions of Milinda. ${ }^{48}$ The story tells about the bodhisatta Lomasa Kassapa, whose passion for a princess Candavati drove him to perform a brutal sacrificial act. Although under Buddhist standards he committed the offense of killing, the text indicates that he was not fully responsible because the act was performed when he was out of his mind and not when he was intending what he was doing. Although on the face of it Lomasa controlled his actions and executed them in conformity with his desires (FW2), on a deeper level, says the Questions of Milinda, his mind was so confused, agitated, and disturbed (vikkhitta-bhanta-lulita-citta) as to prevent real choice. His actions, therefore, are said to have been performed without intention (no sañcetanena).

Conscious reflection and planning-whatever Pāli terms are used to describe them-stand out as necessary components of the Buddhist path to liberation. When the Buddha instructs his son Rahula he tells him to reflect before, during, and after performing any action, because otherwise he would automatically and unconsciously follow his habits and dispositions. The Buddha tells Rahula to reflect:

Would this bodily action that I desire to do (kattukāmo) lead to harming myself, or to harming others or to harming both? Is it an unwholesome bodily action with painful consequences and painful results? 49

Reflection on desire and its consequences allows Rahula to inhibit certain desires and to perform others. As Dennett suggests, becoming a free agent requires knowing one's own desires, and requires knowing, or at least imagining, the consequences of one's actions. A mind colored with lust, hatred, or confusion cannot 
plan appropriately and is limited by its own state. A clear mind is a good guide to one's own desires and is a powerful tool that turns knowledge into wise decisions. This is, in practice, an exercise of conscious will. It is not ultimately free, but only free to the extent that the mind is not overloaded emotionally, is able to be aware of its own state, and is able to imagine future consequences.

\section{Determinism and Fatalism}

The previous two sections argue that there are in fact two definitions of free will of which only one is compatible with what the Buddha taught. The Buddha rejected free will as a power that belongs in the soul, that transcends the physical and that has ultimate control (FW1). On the other hand he accepted the idea that people have free will when they are able to control their actions in conformity with their will when there are no constraints, coercions, and compulsions on either planning or performance (FW2). One objection may be raised against the second definition: if determinism is true, is it not the case that one is already under the control of determinism? Two issues are raised here for Buddhism. First, did the Buddha think that determinism was true? If he did not, then the objection for FW2 is dropped. However, if he did, does determinism imply that agents are controlled and therefore not free?

The idea that the Buddha rejected determinism is a prevalent but inaccurate view. Determinism is the thesis that the past determines a unique future. ${ }^{50}$ This thesis implies that past events causally determine future events so that at any instance there is exactly one possible future. Early Buddhist thought seems to provide a causal theory that accords with this thesis, not rejects it. The best known Buddhist causal formula is "dependent-arising" (pațiccasamuppāda), which explains how various aspects of human life arise in dependence on each other. It takes a form of a causal sequence that typically goes from ignorance to suffering in twelve stages. Nevertheless, other variants are found as well, a fact that emphasizes the generality of the causal principle: certain events causally determine others. ${ }^{51}$ The general principle is commonly expressed in the short formula: "When this exists, that comes to be; with the arising of this, that arises." 52 Another passage from the Nidānavagga suggests that we are dealing here with a theory of specific causality (idappacayatā) which is an independent principle. The passage says:

What is dependent-arising? 'With birth as condition, ageing' — whether Tathāgatas appear or Tathāgatas do not appear-this principle still stands as the stability of the truth, the certainty of the truth, specific conditionality. ${ }^{53}$

This means that the truth (dhamma) of dependent-arising holds independently of the one who recognizes it (a Tathāgata, a Buddha). This principle (dhātu) of specific conditionality, is fixed, sure, or certain (niyāmata). This means that whenever the condition is present, it is certain that the outcome happens, regardless of anyone realizing it or teaching it. The commentary and sub-commentary are even more explicit on this being a description of deterministic causal relations: 
'This principle still stands': the principle is the intrinsic nature of the conditions; never is it the case that birth is not a condition for ageing-and-death. 'The stability of dhamma, the certainty of dhamma': By the next two terms too he indicates just the condition. For the dependently arisen phenomena stand because of the condition; therefore, the condition itself is called 'the stableness of the dhamma.' The condition determines the dependent phenomena; thus it is called the 'certainty of dhamma.' 54

And the sub-commentary goes even further:

Now this is [what is meant by] 'never is it the case that birth is not a condition for ageing-and-death': becoming-as-condition fixes aging-and-death. As it is said of both cases, when there is becoming-as-condition, then he explains the inevitable product (avassambhāvitaṃ). ${ }^{55}$

Evidently this cannot apply for all the conditions of dependent-arising; sensations do not necessarily cause craving (if they were, the end of craving would happen only in deep unconsciousness or death). But this Theravādin commentarial lean toward determinism reflects, I think, a broader Buddhist description of reality as regulated by deterministic causality. It is not necessary to be as radical as to state that in this causality a single event determines another single event. Even if dependent-arising is not a linear causal sequence, it still describes certain aspects of reality as products of conditioning. When the specific conditions mentioned in the formula exist, and when other conditions mentioned elsewhere come together, an outcome will necessarily arise. In their absence, the outcome will not arise.

Dependent arising is specific to human experience, but causality in general is not limited to that. Kalupahana argues that in Buddhist philosophy "everything in this universe comes within the framework of causality." 56 Although Buddhism is mostly concerned with psychological causality, Kalupahana provides references to several instances in the Pāli canon and other early Buddhist texts where different kinds of events are given causal explanation, including natural disasters, weather, plant life, and human behavior. To this he adds reference to a later scholastic discussion that enumerates five spheres in which the causal order operates: the physical, the organic, the psychological, the karmic, and the spiritual. ${ }^{57}$ Nothing in the universe seems to escape these categories.

In addition to this, the Buddha certainly rejected the thesis of fortuity (adhiccasamuppanna-vāda). Among the sixty-two erroneous theories that are rejected in the Brahmajāla-sutta, the Buddha rejects the view that either the world or the self arises by chance. ${ }^{58}$ On another occasion he rejects the idea that the experience of happiness and suffering arises by chance. ${ }^{59}$ The term adhiccasamuppanna is curious because it phonologically resembles the negation of paticcasamuppanna. Although the former is in fact etymologically unrelated to the latter, they function in Buddhist thought as antonyms: "what has arisen by chance" as opposed to "what has arisen by cause." 60 The evidence suggests that there is a tendency, if not a commitment, in early Buddhism to determinism as defined above.

The Buddhist theory of causality does not contradict the theory of kamma (karma), which says that specific intended actions contribute to the arising of specific 
results in the future. Although there are no strict deterministic relations between the act and the result, this does not contradict determinism at all. A result is determined by a combination of various elements including, for example, the level of physical development, behavioral history, level of intelligence, and general life circumstances of the person who performed the moral act. ${ }^{61}$ Thus, similar actions performed by two different individuals may result in different consequences. This does not mean that "the Buddha's conception of causality is more conditional than deterministic,"62 but that karma is only one factor among many in determining the future of human experience. Harvey shows how this is the case when a particular experience is not determined by kamma alone but can arise from one of many other conditions: "bile ... phlegm ... a change of season ... the stress of circumstances," and so on. ${ }^{63}$ Any experience is part of a causally regulated reality in which past events determine future events.

It is possible to conclude that the opposite of the Buddhist theory of causality is not free will, or freedom, but indeterminism (addhiccasamupanna-vāda), which was explicitly rejected by the Buddha. This is often overlooked or at least understated in Buddhist scholarship perhaps because of the common confusion between determinism and fatalism. The latter is an ethical stance that states that choice is meaningless. Niyativāda, the theory of Makkhali Gosala is fatalism, and is rejected by the Buddha because of that, not because of its being determinism. Most signs indicate that Makkhali Gosala also believed in a kind of determinism, in which certain cosmic principles govern the amount of pain and pleasure inflicted upon beings. This aspect of Makkhali's view is not at odds with the Buddhist doctrine, which accepts that manifestation of pleasure and pain is governed by 'law' or regularity (i.e., kamma). Buddhism is at odds with Makkhali's view when the latter claims that purification happens without cause (hetu) or condition (paccaya) within the individual. In other words, all the causes for pleasure and pain are external to the person, who can do nothing for his or her purification. ${ }^{64}$ In addition, he says that there is no agency (attakāra), will (vīriyam), or human exertion (purisaparakkama). ${ }^{65}$ This is an ethical position about what people can and cannot do. The Buddhist rejection of this view is not a rejection of a deterministic theory of causality but a rejection of fatalism. The confusion between fatalism and determinism lies at the heart of the above-mentioned objection (that determinism implies that agents are controlled by causality). Again Dennett provides a helpful analysis that shows that while free will is incompatible with fatalism (or, in his words, "inevitability") it is compatible with determinism.

The central point in Dennett's argument is that free will can operate only in a deterministic reality where future events can be anticipated. It will be hard to account for this type of free will in an indeterministic reality where events happen with no apparent reason or order. For Dennett there is no doubt that the world is deterministic in the sense described above: that there is at any instance exactly one future. But this, he argues, does not imply inevitability. This term is an antonym of "evitability," which means an ability to avoid. Freedom, he suggests, is the ability of agents to avoid certain future scenarios (and thus to achieve others). In this sense, 
some future scenarios are "evitable" for them. ${ }^{66}$ The fact that there is only one future may seem to imply that reality controls agents, and that there is no real freedom. However, Dennett argues, there is a substantial conceptual error in this argument. Control is something agents do. Reality, not being an agent, does not control anything. ${ }^{67}$ Arguments for inevitability usually overlook the fact that the one possible future already includes the agent's predictions, considerations, wishes, decisions, and actions. These are usually inaccessible in advance simply because they are the agent's making. In addition, because knowledge of the present and the past is always limited, any attempt to describe the future in advance would be only an approximation of possible world situations. The point of view of an all-knowing mind, which may know exactly how the future will be, is irrelevant because all-knowing minds do not exist. All points of view are in the world. This leaves agents with plenty of elbow room to speculate, consider, and decide.

There is some evidence that this view is compatible with how the Buddha understood freedom. First, he mocked the idea that there was an all-knowing God that transcended the causally operated universe. ${ }^{68} \mathrm{He}$ also denied that he had perfect knowledge of all things. ${ }^{69}$ For human beings the future is only partially accessible through speculation and inference, because unlike the present it is not directly accessible to experience. Kalupahana explains:

[E]xperiential knowledge (dhamme-ñāna) consists of knowledge of causally conditioned phenomena (pațiccasamuppāda) of the present and partly of the past. Inferential knowledge (anvaye-ñanna) is primarily of the future and partly of the past. ${ }^{70}$

He adds that "this may be the reason why none of the extra-sensory perceptions refer to the future." 71

Human choice and endeavor has a causally effective power within a causally operated reality. In other words, the fact that reality is deterministic does not contradict the ability of agents to speculate and reflect about what to do next and decide accordingly. This kind of free will-imperfect and limited, but not powerless and irrelevant-is not the opposite of determinism but the opposite of fatalism. While determinism means that events happen because other events caused them, it is silent on whether agents cause anything; determinism may well be true in a world without agents at all. On the other hand, fatalism is an ethical stance because it says that agents do not have the power to cause anything and that therefore there is no point in trying. This has, of course, far-reaching ethical implications that are not overlooked by the Buddha.

\section{Conclusion}

The Cartesian and Brahmanical understandings of free will refer to a power that belongs in the soul, that transcends the physical, and that has ultimate control over the body. The Buddha rejects this notion and at the same time rejects fatalism, which leaves no room for significant choices. This rejection is similar in many aspects to the contemporary rejection of the Cartesian notion of free will as expressed in 
Dennett's work. Both Dennett and the Buddha do not accept the idea of a God-like eternal soul, and argue that there is no ultimate control that transcends causality and that entertains supreme mastery of the body.

Dennett's alternative is expounded systematically in the modern Western philosophical manner. It includes redefining free will as the agent's ability to control action according to will whenever there are no constraints, coercions, and compulsions that limit performance. He adds an important cognitive layer to the analysis and shows how imagination of possibilities, prediction, and self-control are the basic functions that make agents free. One of Dennett's main contributions to the free-will debate is the distinction between determinism as a metaphysical position and inevitability, or fatalism, which are ethical positions.

The Buddhist treatment of free will has to be extracted from the doctrine, as the doctrine is by no means a systematic philosophical treatise. Nevertheless, it is clear that the Buddha saw that freedom has a negative correlation with compulsions. While the Western tradition tends to emphasize external compulsion and social freedom, Buddhist doctrine tends to emphasize internal compulsions and psychological freedom.

Much of the confusion around whether the Buddha taught free will can be avoided by dropping the Cartesian model and using a compatibilist model. Buddhist doctrine contains a version of compatibilism that may explain the seemingly contradictory statements given by some scholars: Buddhism rejects the idea that free will exists outside the causal nexus, and at the same it affirms that people can choose and take responsibility for their choices. Choosing right action is not derived from a supernatural or super-causal origin. It is derived from wise contemplation over the possible consequences. This wisdom enables free will, and is a faculty that can be developed. What limits free will is not causality itself, but various mental compulsions. The kind of free will that the Buddha taught is the acquired ability for clear reflection and wise choice that emerges with their eradication.

Notes

1 - Here are two recent examples. One Buddhist philosopher and scholar says: "Do we have free will? Regarding the question, in Buddhism the answer is 'of course not.' There is no autonomous decision process independent of any circumstances, or outside the causal nexus" (Alan B. Wallace and John Searle, Consciousness East and West [Northwestern University, Cognitive Science Program, 2005], Internet video broadcast). On the other hand, another scholar thinks that the Buddha did teach free will: "The Buddha preached an idea of moral agency and individual responsibility which is far stronger than that held by Christianity or indeed by any other religion or ideology of which I am aware. In the first place there is no external agent, such as a God, who can take the blame for our decisions. We have free will and are wholly responsible for ourselves" (Richard Gombrich, "Appreciating the Buddha as a Pivotal 
Figure in World History," in The Bukkyo Dendo Kyokai Lectures [London, 2006], 1st lecture, p. 7).

2 - It has become a convention of the profession to state that by "the Buddha" one means "the Buddha as depicted in this or that scriptural collection." In this article I refer to the Buddha as depicted in the Pâli canon.

3 - Nicholas F. Gier and Paul Kjellberg, "Buddhism and the Freedom of the Will: Pali and Mahayanist Responses," in Freedom and Determinism, ed. Joseph Keim Campbell, Michael O'Rourke, and David Shier (Cambridge, MA: MIT Press, 2004).

4 - Luis O. Goméz, "Some Aspects of Free Will Question in the Nikāyas," Philosophy East and West 21 (1) (1975).

5 - Mark Siderits, "Beyond Compatibilism: A Buddhist Approach to Freedom and Determinism," American Philosophical Quarterly 24 (2) (1987).

6 - Ibid., p. 153.

7 - Ibid., p. 158.

8 - Ibid.

9 - T. Stcherbatsky, Buddhist Logic, vol. 1 ('S-Gravenhage: Mouton, 1958), p. 132.

10 - Dīgha Nikāya I.2 (hereafter D).

11 - Walpola Rahula, What the Buddha Taught, 1st ed. (London: Gordon Fraser, 1959), p. 54.

12 - Chap. 7, sec. 4 of Augustine, The Confessions, trans. Philip Burton (London: Everyman's Library, 2001).

13 - René Descartes, "Meditations on First Philosophy," in Discourse on the Method and Meditation on the First Philosophy, ed. David Weissman (London: Yale University Press, 1641/1996), p. 86.

14 - In Robert Kane, A Contemporary Introduction to Free Will (Oxford: Oxford University Press, 2005), p. 13.

15 - Descartes, "Meditations on First Philosophy," p. 86.

16 - René Descartes, "The Passions of the Soul," in The Philosophical Works of Descartes, ed. Elizabeth S. Haldane (Cambridge: Cambridge University Press, 1649/1967), pp. 352 ff.

17 - John Foster, The Immaterial Self (London: Routledge, 1991), p. 267.

18 - An anti-Cartesian account of free will is provided by the psychologist Daniel Wegner. He rejects the Cartesian model altogether and concludes that free will cannot and does not exist as an active conscious causal power. In other words, he argues that although we feel that we are agents and in control of our actions, this is just an illusion. Wegner rejects the idea that free will belongs 
in an immaterial substance that miraculously influences the body without being influenced by it. He thus remains faithful to the materialistic causal worldview. Wegner's conclusion is a naturalistic solution to the Cartesian problem: souls do not exist, and therefore free will must be an illusion. See Daniel M. Wegner, The Illusion of Conscious Will (London: MIT Press, 2002).

19 - J. R. Searle, Freedom and Neurobiology: Reflections on Free Will, Language, and Political Power (New York: Columbia University Press, 2007).

20 - Few readers commented on my translation of ātman as "soul" (see also Paul Williams and Anthony Tribe, Buddhist Thought: A Complete Introduction to the Indian Tradition [London: Routledge, 2000], pp. 56-57). Indeed, there is a problem with any translation of this word, which is a reflexive pronoun on the one hand and a metaphysical concept on the other. The metaphysics of àtman, I argue, is quite similar to the metaphysics of "soul" in the Cartesian context. It is a non-material substance that both is the true essence of the person and takes part in (or is identical with) the divine. In a private conversation (July 2007) Paul Williams argued that using the word "soul" for àtman completely ignores pre-seventeenth-century conceptions of the term (e.g., the Aristotelian conception of the soul). However, I think that it would be adequate for most postseventeenth-century philosophical thought, which is the context of this article. The word soul, in its post-Cartesian sense, captures much of the meaning of the Sanskrit ātman.

21 - A common mistake, according to Patrick Olivelle; see Patrick Olivelle, The Upanișads (Oxford: Oxford University Press, 1998), p. Ivi.

22 - Bṛhadāranyaka Upanișad (hereafter BṛU) 1.3.28. All citations from the Upanișads are from Olivelle, The Upanișads.

23 - Steven Collins, Selfless Persons (Cambridge: Cambridge University Press, 1982).

24 - Ibid., p. 61.

25 - BṛU 3.7.3 (Olivelle, The Upanișads, slightly altered).

26 - Bṛ 3.7.22.

27 - Saṃyutta Nikāya II.33 (hereafter S).

28 - Rejecting theories about the soul (attānudițthi); e.g., D II.22, S III.85, Anguttara Nikāya III.447 (hereafter A).

29 - S III.66.

30 - Rūpa, vedandā, saññā, saṃkharas viññāṇa. 'Body' here, means the living body, not just the flesh as an unanimated material. I follow Hamilton's English translation which agrees with the Gethin's analysis of these terms. See Hamilton, S. Early Buddhism: A New Approach: The I of the Beholder: (London: Routledge, 2000) p. 18 \& Gethin, R. "The Five Khandhas: Their Treatment in the Nikāyas and Early Abhidhamma." Journal of Indian Philosophy 14, no. 1 (1986): 35-53. 
31 - E.g., BrU 4.3.21 ff.

32 - Majjhima Nikāya I.231 (hereafter M).

33 - Daniel Dennett, Freedom Evolves (London: Allen Lane, 2003), p. 13.

34 - lbid., p. 1.

35 - Ibid., p. 2.

36 - Ibid., pp. 267-268.

37 - Daniel Dennett, "Elbow Room: The Varieties of Free Will Worth Wanting" (Oxford: Clarendon, 1984), pp. 52 ff.

38 - I do not mean the Buddhist text known under this title, although it, too, demonstrates this issue.

$39-$ M I.274.

$40-$ D I.75, M I.275.

41 - David Kalupahana, A History of Buddhist Philosophy: Continuities and Discontinuities (Honolulu: University of Hawai'i Press, 1992), p. 91.

$42-$ D I.53.

43 - A III.338. Harvey mentions this passage in passing, indicating that ārabbhadhātu is an "element of initiating, ... some kind of locus of choice" (Peter Harvey, "'Freedom of the Will' in the Light of Theravāda Buddhist Teachings," Journal of Buddhist Ethics 14 [35-98] [2007]: 3). There is a danger in this terminology, I think, if one interprets it as being a real autonomous centre of choice-although I do not think this meaning was intended by Harvey. The Pali-English Dictionary indicates that dhātu can be understood as principle, natural condition or property (Rhys-Davids T. W. \& W Stede, The Pali Text Society's Pali-English Dictionary. [Chipstead: Pali Text Society, 1921-5]: dhātu 2[a], p. 340), but when speaking of dhātu as in cakkhudhātu, the meaning is 'the faculty of vision.' Because it is nonsensical to talk about the 'faculty of standing' and the 'faculty of approaching' I translate 'dhātu' here as 'ability.'

44 - D II.312.

$45-$ A III.415.

$46-$ M I.56-60.

47 - Dhammapada 1.

48 - Questions of Milinda 200 (I thank Peter Harvey for bringing this passage to my attention. See also Harvey, "'Freedom of the Will' in the Light of Theravāda Buddhist Teachings").

$49-$ M I.415.

50 - Peter Van Inwagen, An Essay on Free Will (Oxford: Oxford University Press, 1983), p. 2. 
51 - See S II.1 for the classical twelve-link formula. Variants are, for example, S II.104 and D II.64.

$52-\mathrm{S}$ II.28.

53 - S II.25.

54 - Sāratthappakāsini (saṃyuttanikāya-ațthakathā) 2.40

55 - Nidānavaggaṭ̄kā, from Chațtha Sañgāyana CD-ROM, Version 3, (Dhammagiri: Vipassana Research Institute, 1999) VRI page reference: 2.42.

56 - David Kalupahana, Buddhist Philosophy: A Historical Analysis (Honolulu: University of Hawai'i Press, 1976), p. 30.

57 - Ibid.

$58-$ D I.28.

59 - S II.22.

60 - Kalupahana even speculates that they are etymologically related. See David Kalupahana, "The Problem of Psychological Causation and the Use of Terms for 'Change' in the Early Buddhist Texts," Vidyodaya 2 (1) (1969): 41.

61 - A I.249.

62 - Kalupahana, Buddhist Philosophy: A Historical Analysis, p. 50. I thank Frank Arthurs, whose unpublished essay directed me to this quote and suggested this criticism.

63 - Harvey, "'Freedom of the Will' in the Light of Theravāda Buddhist Teachings," p. 52.

64 - D I.53.

$65-$ D I.54.

66 - For Dennett's argument for "evitability" see Dennett, Freedom Evolves, pp. 5660.

67 - Dennett, "Elbow Room: The Varieties of Free Will Worth Wanting," pp. 61.

68 - D I.18.

69 - M I.481.

70 - Kalupahana, Buddhist Philosophy: A Historical Analysis, p. 30.

71 - Ibid. 